\title{
PENGEMBANGAN PERANGKAT PEMBELAJARAN IPA BERBASIS $5 E$ LEARNING CYCLE UNTUK MELATIH KEMAMPUAN BERPIKIR KREATIF SISWA SMP
}

\author{
Elga Hary Saputro ${ }^{1)}$, Yuni Srirahayu' ${ }^{2}$, Muhammad Thamrin Hidayat ${ }^{3)}$ \\ ${ }^{1)}$ Mahasiswa Program Studi Pendidikan Sains, Program Pascasarjana Universitas Negeri Surabaya \\ ${ }^{2), 3)}$ Dosen Pascasarjana Prodi Pendidikan Sains Univesrtitas Negeri Surabaya \\ E-mail:elga_hary@yahoo.co.id
}

\begin{abstract}
Science teaching and learning process in school only emphasize on the aspects accepting of knowledge, remembering, and logical thinking, while students creative thinking aspects get less attention. Teachers did not implement the teaching activity that emphasizes the creative thinking because of limited time to make teaching and learning amaterials wich can facilitate students creative thinking skill. This research aimed to produce science teaching and learning set that are feasible, practical, and effective to facilitate creative thinking skill of junior high school students. This research was conducted to implement the teaching and learning materials based on $5 \mathrm{E}$ Learning Cycle model. The subjects of this research was teaching and learning materials. This development research was develop using Dick-Carey's model and try out research using one group pre-test posttest design. Try out was conducted in 7th grade students of SMPN 6 Kediri. The data analysis technique used descriptive qualitative. The results showed: (1) the teaching and learning set was developed feasible with good category; (2) learning implementation get good category; (3) the students more active in learning; (4) student creative thinking skill get high category gain score; (5) the students give positive response with very strong category toward teaching and learning process. Based on this results, it can be concluded that the science teaching and learning materials based on $5 \mathrm{E}$ Laerning Cycle model has been developed are feasible, practical, and effective to facilitate students creative thinking skill.
\end{abstract}

Keywords: 5E Learning Cycle Model, Creative Thinking Skill

\begin{abstract}
Abstrak: Proses pembelajaran IPA di sekolah hanya menekankan pada aspek penerimaan pengetahuan, ingatan dan berpikir logis sedangkan aspek berpikir kreatif siswa kurang diperhatikan. Guru belum melaksanakan pembelajaran yang menekankan pada proses berpikir kreatif karena keterbatasan waktu dalam menyusun perangkat pembelajaran yang dapat melatihkan kemampuan berpikir kreatif. Penelitian ini bertujuan untuk menghasilkan perangkat pembelajaran IPA yang valid, praktis, dan efektif untuk melatihkan kemampuan berpikir kreatif pada siswa SMP. Pembelajaran ini dilakukan dengan cara menerapkan perangkat pembelajaran berbasis $5 E$ Learning Cycle. Sasaran penelitian adalah perangkat pembelajaran. Penelitian ini merupakan penelitian pengembangan dengan model Dick-Carey dan desain ujicoba penelitian menggunakan one group pre-test post-test. Uji Coba dilaksanakan pada siswa kelas VII SMP Negeri 6 Kediri. Teknik analisis data menggunakan deskriptif kualitatif. Hasil analisis data penelitian menunjukkan bahwa: (1) perangkat yang dikembangkan valid dengan kategori baik; (2) pembelajaran terlaksana dengan kategori baik; (3) siswa lebih aktif dalam pembelajaran; (4) kemampuan berpikir kreatif menunjukkan skor Ngain berkategori tinggi; (5) Siswa memberikan respon positif dengan kategori sangat kuat terhadap pembelajaran. Berdasarkan hasil penelitian di atas, dapat disimpulkan bahwa perangkat pembelajaran IPA 5E Learning Cycle yang telah dikembangkan valid, praktis, dan efektif untuk melatih kemampuan berpikir kreatif siswa
\end{abstract}

Kata kunci: Model 5 E Learning Cycle, Kemampuan Berpikir Kreatif

\section{PENDAhuluan}

Sumber Daya Manusia merupakan aset penting suatu negara. Sumber Daya Manusia yang berkualitas merupakan salah satu faktor yang menentukan masa depan bangsa dan negara. Pemerintah dari waktu ke waktu senantiasa berusaha untuk meningkatkan kualitas sumber daya manusia Indonesia, salah satunya melalui dunia pendidikan. Melalui pendidikan yang berkualitas akan dihasilkan sumber daya manusia yang siap dan mampu bersaing dalam menghadapi tantangan Abad 21. Generasi yang kreatif dan berkarakter kuat merupakan generasi yang mampu bersaing di era persaingan global (Kemendikbud dalam Husamah dan Yanur, 2013). Kemendikbud juga menekankan bahwa tujuan pendidikan sekarang ini lebih difokuskan untuk mempersiapkan siswa menjadi pribadi yang kreatif.

Tujuan yang telah dijelaskan di atas ternyata belum tercapai secara maksimal. Sekolah-sekolah di Indonesia secara umum cenderung melatih siswa dalam hal penerimaan pengetahuan, ingatan, dan penalaran atau berpikir logis sehingga sedikit porsi yang diberikan untuk melatihkan kemampuan berpikir kreatif 
(Munandar, 2009). Sejalan dengan pendapat tersebut hasil survey internasional terhadap siswa usia 15 tahun yang diselenggarakan oleh Program for International Student Assessment (PISA) pada Tahun 2012 menunjukkan keterampilan berpikir dalam bidang sains siswa Indonesia masih rendah. Indonesia hanya berada pada peringkat 64 dari 65 peserta dengan skor 382 dengan rata-rata skor seluruh peserta mencapai 500 . PISA mengelompokkan hasil tes peserta dalam beberapa level, yaitu Level 1 sampai Level 6. Secara internasional, Level 2 dianggap sebagai level kecakapan dasar pada skala PISA. Siswa yang gagal mencapai Level 2 dianggap belum memperoleh keterampilan dan pengetahuan yang memadai untuk dapat berpartisipasi dalam angkatan kerja abad ke-21 (Thomson et al., 2013). Survey ini juga menunjukkan fakta bahwa sebesar $66,6 \%$ siswa Indonesia belum memiliki kemampuan dasar yang disyaratkan untuk dapat bersaing di Abad 21. Salah satu keterampilan Abad 21 adalah berpikir kreatif yang saat ini menjadi salah satu fokus pendidikan berbagai negara dunia (Piirto, 2011).

Berdasarkan hasil observasi awal yang dilakukan dengan menggunakan tes berpikir kratif yang telah diberikan kepada siswa SMPN 6 Kediri sebagai sampel, dapat diketahui bahwa sebanyak $83,3 \%$ masuk kategori kurang kreatif, 13,3\% cukup kratif, dan 3,3\% kreatif. Hasil wawancara dengan guru IPA SMP Negeri 6 Kota Kediri, diketahui bahwa selama ini pembelajaran yang melibatkan berpikir kreatif siswa kurang berjalan maksimal. Salah satu penyebabnya adalah keterbatasan waktu guru dalam mengembangkan perangkat pembelajaran yang dapat melatih kemampuan berpikir kreatif pada siswanya. Selama ini guru belum maksimal melaksanakan pembelajaran konstruktivis, sehingga siswa kurang terlibat aktif dalam proses pembelajaran. Guru beranggapan bahwa keberhasilan siswa dalam belajar ditentukan oleh hasil belajar pada aspek pengetahuan saja. Sedangkan aspek yang lain cenderung diabaikan.

Berpikir kreatif merupakan kemampuan untuk memberikan macam-macam kemungkinan jawaban atau pemecahan masalah berdasarkan informasi yang diberikan dan mencetuskan banyak gagasan terhadap suatu persoalan, mencoba menghasilkan sejumlah kemungkinan jawaban atau pemecahan masalah (Yamin, 2013). Munandar (1992) menuliskan 4 indikator berpikir kreatif yaitu: fluency (berpikir lancar), flexibility (berpikir luwes), originality (berpikir asli), dan elaboration (berpikir rinci).

Kemampuan berpikir kreatif dapat dilatihkan melalui strategi belajar mengajar yang banyak memberikan kesempatan kepada siswa untuk terlibat secara aktif dalam bekerja dan berpikir secara mendalam, mengungkapkan dan menguji ide-idenya, serta memfasilitasi siswa dengan berbagai sumber pembelajaran yang dapat membangkitkan rasa ingin tahunya (Qarareh, 2012).

Salah satu model pembelajaran yang sesuai dengan pendekatan ilmiah dan dapat melatih kemampuan berpikir siswa dan mendorong siswa untuk aktif, interaktif, dan bersikap positif selama pembelajaran adalah model $5 E$ Learning Cycle. Model ini memiliki struktur yang menyediakan aktivitas untuk meningkatkan kemampuan belajar dan kreativitas siswa serta menggabungkan hal yang dipelajari dengan fenomena yang ada dalam kehidupan sehari-hari (Kolin dalam Risdiana dkk, 2014). Model $5 E$ Learning Cycle terdiri dari lima fase yaitu Engagement (menarik perhatian siswa), Exploration (melakukan eksplorasi), Explanation (memberikan penjelasan), Elaboration (memperluas konsep), Evaluation (melakukan evaluasi) (Bybee et al.,2006). Aktivitas dalam tahaptahap tersebut berpotensi membantu siswa dalam mengembangkan keterampilan Abad 21 (Bybee, 2009), keterampilan tersebut termasuk juga berpikir kreatif. Siswa yang terlatih untuk berfikir kreatif cenderung lebih mampu menguasai suatu konsep tertentu dengan baik, sesuai dengan pernyataan Piaget (Slavin, 2011) bahwa belajar dapat diartikan sebagai tindakan kreatif dalam pembentukan konsep melalui kegiatan berpikir tentang benda dan peristiwa yang mereka alami. Sejalan dengan hasil penelitian Yalcin dan Bayrakceke (2010), siswa yang belajar menggunakan model $5 E$ Learning Cycle lebih memahami konsep yang. Kemampuan berpikir kreatif dan motivasi belajar siswa juga mengalami peningkatan yang signifikan melalui model pembelajaran $5 E$ Learning Cycle (Hardiyasa dkk (2014), Manuhutu (2014)).

Melatihkan berpikir kreatif kepada siswa melalui kegiatan pembelajaran haruslah direncanakan dengan baik, oleh karena itu diperlukan perangkat pembelajaran yang mendukung kegiatan-kegiatan untuk melatihkan berpikir kreatif dalam pembelajaran. Perangkat tersebut meliputi silabus, RPP, LKS, Buku Ajar Siswa, serta Lembar Penilaian yang dapat mendukung proses pembelajaran untuk melatih kemampuan berpikir kreatif. Berdasarkan uraian di atas maka peneliti akan melakukan penelitian dengan judul "Pengembangan Perangkat Pembelajaran IPA Berbasis Model 5E Learning Cycle untuk Melatih Kemampuan Berpikir Keatif Siswa SMP”.

Permasalahan penelitian ini adalah "Bagaimana kelayakan perangkat pembelajaran IPA berbasis model $5 E$ Learning Cycle untuk melatih kemampuan berpikir keatif pada siswa SMP?". Berdasarkan permasalahan penelitian di atas, maka tujuan dari penelitian ini adalah untuk menghasilkan perangkat pembelajaran IPA berbasis model $5 E$ Learning Cycle yang layak untuk melatih kemampuan berpikir keatif pada siswa SMP. 


\section{METODE PENELITIAN}

Penelitian ini merupakan penelitian pengembangan yang mengembangkan perangkat pembelajaran antara lain RPP, LKS, buku ajar siswa, dan instrumen penilaian.

Penelitian ini terdiri dari dua tahap pelaksanaan yaitu tahap pengembangan perangkat pembelajaran dan tahap uji coba perangkat yang telah dikembangkan. Tahap pengembangan perangkat menggunakan model Dick-Carey yang telah disesuaikan dengan keperluan penelitian pengembangan. Tahap uji coba perangkat pembelajaran menggunakan One Group Pretest-Postest Design (Tuckman, 1978). Subjek penelitian ini adalah perangkat pembelajaran berbasis 5E Learning Cycle yang telah dikembangkan, sedangkan subjek uji coba adalah siswa kelas VII SMPN 6 Kediri pada materi pencemaran lingkungan semester 2 tahun pelajaran 2014/2015.

Teknik pengumpulan data dalam penilitian ini adalah dokumentasi, observasi, angket, dan tes. Instrumen yang digunakan untuk mengumpulkan data disusun dengan mengadaptasi dari instrumen-instrumen penelitian sebelumnya dan dikembangkan sesuai kebutuhan penelitian.Instrumen tersebut antara lain: 1) lembar validitas perangkat pembelajaran; 2) lembar pengamatan keterlaksanaan pembelajaran; 3) lembar pengamatan aktivitas siswa; 4) lembar pengamatan kendala dalam pembelajaran; 5) instrumen tes kemampuan berpikir kreatif; 6) angket respon siswa. Teknik analisis data dalam penelitian ini menggunakan deskriptif kualitatif.

\section{HASIL PENELITIAN DAN DISKUSI}

\section{A. Validitas Perangkat Pembelajaran}

Perangkat pembelajaran yang dikembangkan divalidasi oleh dua orang validator ahli dan memperoleh hasil sebagai berikut:

Hasil rata-rata validasi RPP pada aspek format sebesar 3,50 dengan kategori valid, aspek isi sebesar 3,61 dengan kategori sangat valid, dan aspek bahasa sebesar 3,67 dengan kategori sangat valid (Ratumanan \& Laurens, 2006). Hasil tersebut menunjukkan bahwa RPP yang dikembangkan secara umum masuk kategori layak untuk digunakan dalam pembelajaran. Rata-rata reliabilitas dari instrumen validasi RPP adalah 89,64\% dan masuk dalam kategori reliabel (Borich, 1994).

Rata-rata hasil validasi terhadap Lembar LKS pada aspek format sebesar 3,63 dengan kategori sangat valid, aspek isi sebesar 3,75 dengan kategori sangat valid, dan aspek bahasa sebesar 3,50 dengan kategori valid. Ratarata reliabilitas dari instrumen validasi LKS sebesar 91,15\%. Hasil tersebut secara umum menunjukkan bahwa LKS yang telah dikembangkan layak digunakan dalam pembelajaran dan reliabel.

Pengembangan Perangkat Pembelajaran IPA Berbasis $5 E$ Learning Cycle untuk ...
Buku ajar siswa memperoleh rata-rata hasil validasi pada aspek format sebesar 3,70 dengan kategori sangat valid, aspek isi sebesar 3,57 dengan kategori valid, aspek bahasa sebesar 3,67 dengan kategori sangat valid, dan aspek fisik sebesar 3,67 dengan kategori sangat valid. Rata-rata reliabilitas validasi buku ajar siswa sebesar 91,95\% dengan kategori reliabel. Hasil tersebut menunjukkan bahwa buku ajar siswa yang dikembangkan layak untuk dijadikan panduan siswa dalam proses pembelajaran.

Hasil validasi terhadap tes berpikir kreatif dari aspek isi masuk kategori valid dan dari aspek bahasa masuk kategori mudah dipahami, dengan demikian instrumen tersebut layak digunakan.

\section{B. Kepraktisan Perangkat Pembelajaran \\ 1. Pengamatan Keterlaksanaan RPP}

Berdasarkan hasil pengamatan yang dilakukan oleh dua orang pengamat dengan menggunakan lembar pengamatan keterlaksanaan RPP didapatkan hasil seperti dalam Tabel 1 berikut ini:

Tabel 1. Hasil Pengamatan Keterlaksanaan RPP

\begin{tabular}{|l|l|l|l|l|}
\hline No. & $\begin{array}{l}\text { Tahap } \\
\text { Pembelajaran }\end{array}$ & $\begin{array}{l}\text { Rata- } \\
\text { Rata }\end{array}$ & $\begin{array}{l}\text { Katego } \\
\text { ri }\end{array}$ & $\begin{array}{l}\text { Keterla } \\
\text { ksanaan }\end{array}$ \\
\hline 1 & Pendahuluan & 3,89 & Baik & $\sqrt{ }$ \\
\hline 2 & Kegiatan Inti & 3,83 & Baik & $\sqrt{ }$ \\
\hline 3 & Penutup & 3,61 & Baik & $\sqrt{ }$ \\
\hline 4 & $\begin{array}{l}\text { Pengelolaan } \\
\text { Waktu }\end{array}$ & 3,67 & Baik & $\sqrt{ }$ \\
\hline 5 & Suasana Kelas & 3,92 & Baik & $\sqrt{ }$ \\
\hline \multicolumn{7}{|l|}{ Persentase keterlaksanaan (\%) } & 100 \\
\hline
\end{tabular}

Tahap awal pembelajaran adalah pendahuluan. Rata-rata skor seluruh aspek kegiatan pembelajaran dalam tahap pendahuluan dari tiga pertemuan sebesar 3,89 dengan kategori baik (Ratumanan \& Laurens, 2011). Hal ini menunjukkan seluruh kegiatan yang masuk dalam tahapan pendahuluan yaitu: kegiatan berdoa di awal pelajaran, memotivasi siswa, menyampaikan tujuan pembelajaran dapat terlaksana dengan baik. Ketiga kegiatan tersebut masuk dalam fase engagement yang menekankan kegiatan motivasi untuk menarik perhatian dan antusiasme siswa terhadap pembelajaran. Kegiatan pendahuluan yang baik dapat meningkatkan rasa ingin tahu (curiousity) siswa sehingga siswa lebih antusias untuk mengikuti tahap pembelajaran selanjutnya. Meningkatnya antusiasme dan motivasi siswa terhadap pembelajaran juga dapat meningkatkan kemampuan berpikir kreatif siswa (Munandar, 2009).

Tahap berikutnya adalah kegiatan inti. Rata-rata skor pada kegiatan inti sebesar 3,83 yang masuk dalam kategori baik (Ratumanan \& Laurens, 2011). Kegiatan inti terdiri dari empat fase yaitu exploration, explanation, elaboration, dan evaluation yang rata-rata seluruhnya masuk kategori baik. Hal ini menunjukkan 
bahwa pembelajaran yang dilaksanakan telah berjalan sesuai dengan rencana pembelajaran yang telah dikembangkan. Pemberian kesempatan siswa untuk mengeksplorasi pengetahuan dengan setting kelompok pada kegiatan inti memberikan pengalaman bagi siswa untuk terlibat aktif dalam mengkonstruksi sendiri pengetahuannya. Selain itu dengan setting kelompok memungkinkan terjadinya interaksi antara siswa dengan teman lain dapat membantu terbentuknya ide baru dan memperkaya perkembangan intelektual siswa (Vigotsky dalam Ibrahim,2012). Ketika siswa terlibat dalam kegiatan kelompok maka akan terjadi proses scaffolding, dimana siswa dalam satu kelompok saling bekerja sama dan memberikan bantuan kepada anggota kelompoknya yang kurang mampu dalam proses pembelajaran (Vigotsky dalam Slavin, 2011). Tahap kegiatan inti juga memfasilitasi siswa untuk menyampaikan temuan, ide ataupun bertukar pendapat terkait hasil observasi yang telah mereka diskusikan melalui media poster ilmiah yang dibuat sesuai dengan kreatifitas kelompok mereka.

Rata-rata skor kegiatan penutup sebesar 3,61 dengan kategori baik (Ratumanan \& Laurens, 2011). Hal ini karena guru memberikan kesempatan kepada siswa untuk terlibat aktif menyimpulkan materi dan bertanya tentang materi yang belum dipahami sebelum pembelajaran diakhiri. Guru juga membiasakan siswa berdoa diakhir pelajaran. Namun pada kegiatan menyimpulkan materi pembelajaran yang telah dipelajari mendapatkan rata-rata skor 3,33 dengan kategori cukup baik. Hal ini disebabkan siswa belum terbiasa terlibat aktif dalam menyimpulkan pembelajaran, sehingga perlu banyak mendapatkan bimbingan dari guru. Untuk pertemuan kedua dan ketiga pada kegiatan menyimpulkan materi pelajaran mengalami kenaikan rata-rata skor yang menunjukkan siswa mulai terlatih untuk aktif dalam menyimpulkan materi pelajaran.

Aspek pengelolaan waktu memiliki rata-rata skor 3,67 dengan kategori baik (Ratumanan \& Laurens, 2011). Pengelolaan waktu pada pertemuan pertama hanya mendapatkan rata-rata skor 3,00 karena siswa belum terbiasa dengan model pembelajaran yang diterapkan sehingga memerlukan waktu yang lebih pada setiap tahap pembelajarannya daripada waktu yang telah direncanakan. Namun hal ini telah diperbaiki pada pertemuan kedua dan ketiga yang mendapatkan rata-rata skor yang lebih baik dari pertemuan pertama sehingga secara keseluruhan dapat dikatakan bahwa guru sudah dapat memanfaatkan waktu dengan efektif dan efisien dalam mengelola kelas. Aspek suasana kelas memperoleh rata-rata skor sebesar 3, 92 dengan kategori baik. Hal ini menunjukkan siswa dan guru antusias dalam pelaksanaan kegiatan pembelajaran. Suasana kelas yang menyenangkan, memberikan kesempatan yang luas bagi siswa untuk berpendapat dan mengemukakan ide baru merupakan lingkungan yang baik untuk mengembangkan kemampuan berpikir kreatif siswa (Munandar, 1992).

\section{Aktivitas Siswa}

Persentase aktivitas siswa tertinggi pada aktivitas terlibat dalam kegiatan diskusi kelas yaitu sebesar $19,17 \%$, pada pertemuan pertama, $19,38 \%$ pada pertemuan kedua, dan 19,38\% pada pertemuan ketiga. Kegiatan diskusi memfasilitasi siswa untuk menkonfirmasi pengetahuan yang telah didapat melalui proses curah pendapat dengan siswa dari kelompok lain maupun dari guru. Kegiatan ini juga memberikan kesempatan yang luas bagi siswa untuk berani mengungkapkan pendapat serta ide-ide mereka terkait materi pencemaran lingkungan yang sedang dipelajari. Semakin luas kesempatan yang diberikan kepada siswa untuk berdiskusi, mengungkapkan pendapat atau ide yang telah siswa kembangkan maka kemampuan berpikir kreatif mereka semakin terlatih (Feldhusen dan Treffinger dalam Risdiana, 2014).

Aktivitas eksplorasi, menjawab pertanyaan dan menyampaikan pendapat, serta terlibat dalam menyelesaikan masalah penerapan atau perluasan pengetahuan juga memiliki persentase aktivitas yang tinggi. Hal ini menunjukkan bahwa pembelajaran dengan model $5 E$ Learning Cycle merupakan pembelajaran yang mengedepankan peran aktif siswa dalam membangun pengetahuannya sendiri, menemukan gagasan, dan memperoleh makna oleh siswa sendiri (Bruner dalam Arends, 2008). Keterlibatan siswa secara aktif dalam pembelajaran memudahkan siswa untuk mengasimilasi dan mengakomodasi informasi baru sehingga siswa mudah memahami pengetahuan yang sedang mereka pelajari (Piaget dalam Slavin, 2011).

Persentase aktivitas siswa yang kurang relevan dengan pembelajaran juga mengalami penurunan di setiap pertemuan. Hal ini menunjukkan suasana belajar yang diciptakan dapat menarik antusiasme siswa sehingga siswa fokus pada kegiatan pembelajaran. Ketika siswa tertarik pada pembelajaran dan melibatkan diri secara aktif dalam kegiatan pembelajaran maka siswa cenderung tidak akan melakukan akivitas yang kurang relevan (Aydin dan Yilmaz, 2010)

\section{Keefektivan Perangkat Pembelajaran \\ 1. Hasil Tes Berpikir Kratif}

Kemampuan berpikir kreatif siswa diukur menggunakan tes kemampuan berpikir kratif yang terdiri dari lima unit tes. Lima unit tes yang disusun mewakili indikator kemampuan berpikir kreatif yaitu kelancaran (fluency), keluwesan (flexibility), keaslian (originality) dan memerinci (elaboration). Tes kreatif verbal yang dikembangkan dalam penelitian ini 
dikaitkan dengan materi pencemaran lingkungan. Persentase skor tes kemampuan berpikir kreatif siswa yang diukur melalui pre-test dan post-test kemudian dikonversi ke dalam kategori mulai dari kategori tidak kreatif sampai kategori sangat kreatif (Khanafiyah dan Rusilowati, 2010). Persentase skor tes berpikir kreatif siswa disajikan pada Gambar 1 berikut ini:

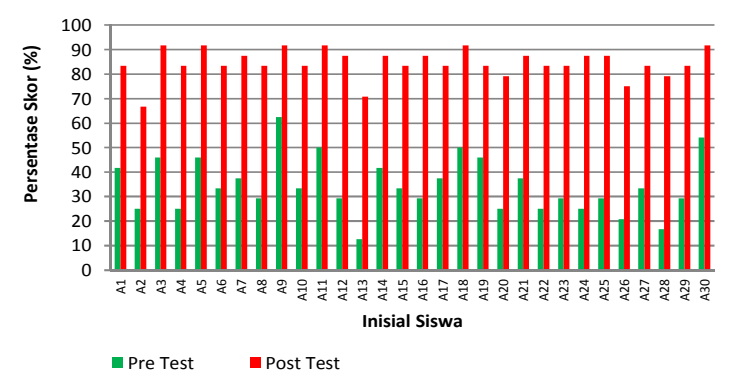

Gambar 1. Grafik Hasil Tes Berpikir Kreatif

Hasil pre-test kemampuan berpikir kreatif siswa menunjukan 2 siswa masuk kategori tidak kratif, 19 siswa masuk kategori kurang kratif, 8 siswa masuk kategori cukup kreatif, dan hanya satu siswa masuk kategori kratif. Siswa merasa tes kemampuan berpikir kreatif seperti yang diujikan merupakan hal yang baru dan belum pernah mereka kerjakan sebelumnya sehingga hasil yang didapatkan kurang maksimal.

Hasil post-test menunjukkan 25 orang siswa mencapai persentase skor dengan kategori sangat kreatif, dan 5 orang siswa masuk kategori kreatif. Hasil tersebut menunjukkan bahwa kemampuan berpikir kreatif siswa mengalami perkembangan setelah mengikuti pembelajaran dengan menggunakan perangkat pembelajaran $5 E$ Learning Cycle yang dikembangkan.

Hal ini diperkuat dengan adanya peningkatan kemampuan berpikir kreatif siswa yang ditunjukkan oleh nilai rata-rata $\mathrm{N}$-gain sebesar 0,77 dengan kategori tinggi (Hake, 1999). Peningkatan kemampuan berpikir kreatif siswa diasumsikan merupakan efek dari pembelajaran 5E Learning Cycle yang telah mereka laksanakan. Kemampuan berpikir kreatif siswa dapat berkembang jika disediakan suatu lingkungan belajar yang kondusif untuk merangsang berpikir kreatif mereka. Pemberian kesempatan yang luas untuk mengembangkan ide dan mengungkapkan ide yang dikembangkan untuk menyelesaikan masalah yang disajikan dalam pembelajaran dapat siswa temukan pada fase exploration, explanation, dan elaboration dalam model 5E Learning Cycle. Hasil yang diperoleh tersebut juga diperkuat oleh hasil dari penelitian terdahulu yaitu penelitian yang dilakukan oleh Susantini dkk (2012), Hardiyasa dkk (2014), Manuhutu (2014) yang menyatakan bahwa Model $5 E$ Learning
Cycle membantu meningkatkan keterampilan berpikir kreatif, hasil belajar, dan motivasi berprestasi siswa.

Setiap fase dalam pembelajaran model $5 E$ Learning Cycle berpotensi untuk dapat melatihkan keterampilanketerampilan yang dibutuhkan pada abad 21 yang mencakup keterampilan berpikir tingkat tinggi (Bybee, 2009). Pernyataan Bybee tersebut juga diperkuat oleh hasil penelitian Aydin dan Yilmaz (2010) yang menyimpulkan bahwa model $5 E$ Learning Cycle memiliki pengaruh yang besar terhadap keterampilan kognitif tingkat tinggi siswa. Kemampuan berpikir kreatif merupakan bagian dari keterampilan berpikir tingkat tinggi.

Peningkatan kemampuan berpikir kreatif siswa terjadi karena pada pembelajaran 5E Learning Cycle siswa dilatih untuk berani mengungkapkan sebanyak mungkin pendapat ataupun idenya untuk menanggapi permasalahan baik berupa gambar ataupun suatu fenomena yang disajikan. Siswa juga dilibatkan secara aktif dalam prosess pembelajaran. Siswa akan dapat belajar dan menyerap ilmu dengan baik jika mereka dapat terlibat aktif dalam proses pembelajaran (Bruner dalam Slavin, 2011).

Fase 5E Learning Cycle yang pertama yaitu engagement mengajak siswa untuk mencermati fenomena dari gambar yang ditampilkan dan mengajukan pendapat sesuai imajinasi mereka terhadap gambar. Hal ini melatih kelancaran siswa dalam berimajinasi dan berpikir. Fase ini juga digunakan sebagai titik awal kegiatan untuk menumbuhkan dan mengembangkan sikap rasa ingin tahu (curiousity) siswa terhadap materi yang akan mereka pelajari (Aydin dan Yilmaz, 2010). Rasa ingin tahu siswa ini nantinya akan diaktualkan dalam bentuk kegiatankegiatan dan sikap ilmiah yang positif dalam pembelajaran, misalnya melalui kegiatan bertanya, menyampaikan pendapat, serta kegiatan menggali pengetahuan melalui buku ajar ataupun berbagai kegiatan-kegiatan yang disediakan guna memfasilitasi proses penggalian informasi dan pengetahuan oleh siswa. Siswa yang pada kegiatan awal pembelajaran telah memiliki rasa ingin tahu yang tinggi akan terdorong untuk bersikap lebih positif terhadap pembelajaran sains yang akan dipelajari (Sayuti dkk, 2012).

Fase exploration dan explanation melibatkan siswa dalam kegiatan pengamatan dan penyelesaian masalah dalam LKS yang memerlukan kelancaran dan keluwesan berpikir untuk dapat menyelesaikan permasalahan dari berbagai sudut pandang. Fase exploration menyediakan kesempatan bagi siswa untuk menuangkan, mempertimbangkan, menyusun ide, mendiskusikan langkah-langkah penyelidikan, dan memberikan pengalaman dalam melakukan eksplorasi atau penyelidikan yang melibatkan kemampuan 
berpikir tingkat tinggi (Tuna dan Kacar, 2013). Pada fase explanation kemampuan elaborasi dan orisinalitas dalam berpikir juga dilatih ketika siswa mempersiapkan penyajian hasil pengamatannya melalui poster ilmiah yang menarik dan sedapat mungkin berbeda dari kelompok lain. Orisinalitas ide juga muncul dan dilatih ketika mereka menghadapi fase elaboration terutama pada pertemuan ketiga dimana siswa dituntut untuk memberikan ide pemanfaatan sampah yang telah mereka pilih. Hal ini didukung oleh hasil penelitian Risdiana (2014) yang menyatakan bahwa model $5 E$ Learning Cycle dapat melatihkan kemampuan berpikir kreatif dan pemahaman konsep pada siswa. Hasil analisis masing-masing unit tes dan indikator kemampuan berpikir kreatif disajikan pada Tabel 4.2 berikut ini.

Tabel 2. Hasil Analisis pada Setiap Unit Tes dan Indikator Berpikir Kreatif

\begin{tabular}{|c|c|c|c|c|c|c|c|}
\hline \multirow[b]{2}{*}{ Unit Tes } & \multicolumn{2}{|c|}{ Total Skor } & \multicolumn{2}{|c|}{ Peningkatan } & \multirow{2}{*}{$\begin{array}{l}\text { Indikator } \\
\text { Kreatif ke- }\end{array}$} & \multicolumn{2}{|c|}{ Peningkatan } \\
\hline & $O_{1}$ & $\mathrm{O}_{2}$ & $\mathbf{N}<\mathbf{g}>$ & & & $\begin{array}{c}\mathbf{N}<\mathbf{g} \\
>\end{array}$ & K \\
\hline I & 39 & 85 & 0,90 & Tinggi & \multirow{2}{*}{ I } & \multirow{2}{*}{0,89} & \multirow{2}{*}{ Tinggi } \\
\hline II & 33 & 83 & 0,88 & Tinggi & & & \\
\hline III & 36 & 83 & 0,85 & Tinggi & II & 0,85 & Tinggi \\
\hline IV & 28 & 69 & 0,69 & Sedang & III & 0,69 & Sedang \\
\hline V & 24 & 68 & 0,65 & Sedang & IV & 0,65 & Sedang \\
\hline
\end{tabular}

Berdasarkan hasil analisis pada setiap unit tes kemampuan berpikir kreatif (Tabel 4.2) dapat diketahui bahwa total skor pre-test siswa pada unit 1 sebesar 39 dan pada post-test total skor siswa adalah 85 dengan $N$ gain sebesar 0,90 berkategori tinggi. Unit 2 juga mengalami peningkatan sebesar 33 dan hasil post-test sebesar 83 dengan $N$-gain 0,88 berkategori tinggi.Peningkatan skor yang diperoleh siswa menunjukkan bahwa siswa lebih mampu berpikir lancar sehingga dapat lebih banyak memberikan jawaban yang relevan setelah melalui proses pembelajaran. Total skor Unit 3 juga mengalami peningkatan yang ditunjukkan dengan skor $\mathrm{N}$-gain sebesar 0,85 dengan kategori tinggi. Hal tersebut menunjukkan peningkatan kemampuan siswa dalam berpikir secara luwes dari berbagai sudut pandang untuk mengungkapkan gagasan dan menyelesaikan permasalahan yang disajikan.

Tes unit 4 meminta siswa untuk memikirkan sebuah ide tentang penggunaan yang tidak biasa dari sebuah obyek yang dituliskan. Hasil skor total pada unit ini mengalami kenaikan dari 28 pada saat pre-test menjadi 71 pada saat post-test dengan $N$-gain sebesar 0,69 yang masuk kategori sedang. Peningkatan tersebut menunjukkan bahwa setelah pembelajaran siswa mampu berpikir secara luwes untuk memberikan jawaban dan melihat suatu permasalahan dari sudut pandang yang berbeda sehingga menghasilkan ide-ide baru yang orisinal. Tes unit 5 yaitu soal apa akibatnya, siswa diminta untuk berpikir secara terperinci. Hasil analisis pada unit ini mengalami peningkatan dengan kategori sedang dengan skor $N$-Gain sebesar 0,65 . Total skor yng diperoleh siswa pada saat pre-test sebesar 24 dan pada saat post-test sebesar 67. Hal ini menunjukkan bahwa siswa telah mampu merinci lebih detail pemikirannya dalam mengembangkan gagasan dan memperluas gagasannya untuk menyelesaikan masalah.
Berdasarkan hasil penghitungan $\mathrm{N}$-gain pada unit 4 dan unit 5 hanya berkategori sedang.

Berdasarkan Tabel 4.2 dapat diketahui bahwa penyumbang skor terbesar pada hasil post-test berpikir kreatif siswa adalah skor dari indikator I (fluency) dan skor indikator 2 (flexibility). Skor $\mathrm{N}$-gain dari sub unit tes 1 , 2, dan 3 yang mewakili indikator fluency dan flexibility juga lebih besar daripada skor $\mathrm{N}$-gain dari sub unit tes 4 dan 5 yang mewakili indikator originality dan elaboration. Hal ini disebabkan oleh kegiatan yang diberikan pada saat proses pembelajaran lebih banyak digunakan untuk melatihkan indikator fluency dan flexibility daripada originality dan elaboration, oleh karena itu perlu latihan yang berkelanjutan dan porsi kegiatan yang lebih banyak untuk lebih mengembangkan kemampuan berpikir kreatif siswa terutama indikator originality dan elaboration.

Levinger (Filsaime, 2008) menyatakan jika guru mampu melatihkan keterampilan berpikir tingkat tinggi, maka siswa akan memiliki kemampuan berpikir kreatif dan berpikir kritis yang sangat dibutuhkan dalam membangun kepribadian yang mandiri yang mampu mengelola sendiri proses belajarnya (self regulated learning), dan mengkonstruksi sendiri pengetahuannya sehingga dapat dikatakan bahwa siswa yang mempunyai kemampuan berpikir kreatif yang tinggi maka akan memperoleh hasil belajar yang tinggi pula.

\section{Respon Siswa Terhadap Pembelajaran}

Berdasarkan hasil analisis respon siswa terhadap pembelajaran dengan menggunakan perangkat berbasis $5 E$ Learning Cycle yang dikembangkan diperoleh ratarata keseluruhan 96,61\% siswa memberikan respon yang positif dengan kategori sangat kuat, dan 3,39\% siswa memberikan respon yang kurang baik terhadap pembelajaran dengan kategori sangat lemah (Riduwan, 2010). Hal ini menunjukkan bahwa siswa memiliki 
minat, senang, dan mendukung pelaksanaan pembelajaran menggunakan perangkat pembelajaran yang telah dikembangkan. Siswa yang memberikan respon kurang baik kurang terlibat aktif dan antusias dalam pembelajaran. Respon positif dari siswa ini diperkuat dengan hasil penelitian dari Prastiwi dan Anggaryani (2014) yang menyatakan bahwa siswa memberikan respon positif terhadap pelaksanaan pembelajaran $5 E$ learning Cycle yang telah dilakukan.

\section{Temuan Penelitian}

Berdasarkan hasil analisis dan pembahasan hasil penelitian pengembangan perangkat dan penerapan pembelajaran 5E Learning Cycle untuk melatihkan kemampuan berpikir kreatif ditemukan hal-hal sebagai berikut:

a. Perangkat pembelajaran IPA berbasis 5E Learning Cycle untuk melatihkan kemampuan berpikir kreatif yang telah dikembangkan dinyatakan valid dan dapat digunakan dalam kegiatan pembelajaran IPA di SMP.

b. Kepraktisan perangkat pembelajaran IPA yang dikembangkan melalui implementasi pada uji coba 2 dilihat dari:

1) Persentase keterlaksanaan seluruh tahapan pembelajaran pada RPP 1, RPP 2, dan RPP 3 masing-masing sebesar 100\% dengan kategori terlaksana sangat baik, sedangkan rata-rata skor pada tiap tahapan pembelajaran masuk dalam kategori baik.

2) Hasil pengamatan aktivitas siswa pada uji coba 2 diketahui bahwa persentase aktivitas yang dominan selama tiga kali pertemuan adalah aktivitas yang melibatkan siswa aktif dalam pembelajaran seperti terlibat aktif dalam kegiatan diskusi kelas, menganalisis data, dan melaksanakan kegiatan pengumpulan data. Berdasarkan hasil di atas dapat disimpulkan bahwa perangkat pembelajaran IPA berbasis $5 \mathrm{E}$ Learning Cycle yang telah dikembangkan praktis dilaksanakan dalam pembelajaran untuk melatihkan kemampuan berpikir kreatif.

c. Keefektifan perangkat pembelajaran melalui implementasi pada uji coba 2 dilihat dari:

1) Penerapan perangkat pembelajaran IPA berbasis 5E Learning Cycle dapat melatihkan kemampuan berpikir kreatif siswa, yaitu: ratarata $\mathrm{N}$-gain sebesar 0,77 dengan kategori tinggi.

2) Siswa merespon sangat positif hasil pengembangan perangkat dan pelaksanaan pembelajaran dengan inkuiri terbimbing. Hal tersebut dapat dilihat dari hasil analisis data respon siswa sebanyak 96,61\% siswa memberikan respon positif dengan kategori sangat kuat.

\section{KESIMPULAN}

\section{A. Simpulan}

Berdasasarkan temuan penelitian yang telah diuraikan di atas, maka dapat disimpulkan bahwa perangkat pembelajaran berbasis $5 E$ Learning Cycle yang dikembangkan dinyatakan valid, praktis, dan efektif sehingga layak untuk melatih kemampuan berpikir kreatif pada siswa SMP dengan materi pencemaran lingkungan.

\section{B. Saran}

Berdasarkan hasil penelitian, terdapat beberapa saran antara lain:

1. Pengembangan perangkat pembelajaran berbasis $5 \mathrm{E}$ Learning Cycle dapat melatihkan kemampuan berpikir kreatif siswa sehingga perlu dikembangkan secara lebih luas pada materi pembelajaran IPA lainnya.

2. Persiapan dan pengelolaan waktu yang baik diperlukan dalam menerapkan pembelajaran model 5E Learning Cycle agar pembelajaran berjalan dengan efektif dan efisien, sehingga siswa mendapatkan banyak kesempatan untuk melatih kemampuan berpikir kreatifnya.

\section{REFERENSI}

Arends, R. I. (2008). Learning to Teach Edisi ke Tujuh. Alih bahasa oleh Helly Prajitno S. dan Sri MS. Yogyakarta: Pustaka Pelajar.

Aydin, N., Yilmaz, A. (2010). The Effect of Constructivist Approach in Chemistry Education on Students' Higher Order Cognitive Skills. H. U. Journal of Education, Vol 39, pp 57-68.

Borich, G. (1994). Observation skill for effective teaching. New York: Mac Millan Publishing Company.

Bybee, R.W., Taylor, J.A., Gardner, Pamela V.S., Janet, C.P., Anne, W., Nancy, L. (2006). The BSCS $5 E$ Instructional Model: Origins and Effectiveness. Mark Dabling Boulevard: Colorado Spring, CO.

Bybee, R. W. (2009). The BSCS 5E Instructional Model and $21^{S T}$ Century Skills. A Commissioned Paper Prepared For a Workshop on Exploring The Intersection of Science Education and The Development of $21^{\text {ST }}$ Century Skills.

Filsaime, D. K., (2008). Menguak Rahasia Berpikir Kritis dan Kreatif. Jakarta: Prestasi Pustakaraya.

Hake. (1999). Analyzing change/gain scores. (Online). Tersedia http://www. physicsindiana.edu/sdi/ Analyzing-Change-Gain. pdf.

Hardiyasa, I. M., Suma, K., Sadia, I. W. (2014). Pengaruh Model Siklus Belajar 5E Terhadap Keterampilan Berpikir Kreatif dan Motivasi 
Berprestasi Siswa. e-Journal PPs Universitas Pendidikan Ganesha Prodi IPA, Vol 4

Husamah, Yanur, S. (2013). Desain Pembelajaran Berbasis Pencapaian Kompetensi. Jakarta: Prestasi Pustakakarya.

Ibrahim, M. (2012). Pembelajaran Berdasarkan Masalah. Surabaya: Unesa University Press.

Khanafiyah, S., Rusilowati, A. (2010). Penerapan Pendekatan Modified Free Inquiry sebagai Upaya Meningkatkan Kreativitas Mahasiswa Calon Guru dalam Mengembangkan Jenis Eksperimen dan Pemahaman Terhadap Materi Fisika. Jurnal Berkala Fisika, Vol 13. No. 2, pp E7 - E17.

Manuhutu, S. (2014). Pengaruh Penerapan Strategi Pembelajaran Learning Cycle Melalui "5e" dalam Mengembangkan Kemampuan Berpikir Kreatif Siswa (Studi Eksperimen Pada Mata Pelajaran Ekonomi Kelas X Smu Negeri 11 Ambon). Jurnal Pendidikan "Jendela Pengetahuan". Vol ke-7, Cetakan ke-17, pp 67-82.

Munandar, U. (1992). Mengembangkan Bakat dan Kreativitas Anak Sekolah. Jakarta: Rineka Cipta.

Munandar, U. (2009). Pengembangan Kreativitas Anak Berbakat. Jakarta: Rineka Cipta.

Piirto, J. (2011). Creativity for $21^{\text {st }}$ Century Skills. Rotterdam: Sense Publishers.

Prastiwi, C.A.S., Anggaryani, M. (2014). Penerapan Strategi Pembelajaran Learning Cycle Tipe 5E Dengan Materi Pesawat Sederhana Sebagai Upaya Meningkatkan Hasil Belajar Siswa SMP Negeri 2 Gedangan Kelas VIII. Jurnal Inovasi Pendidikan Fisika (JIPF). Vol. 03 No. 02, pp. 37-40.

Qarareh, A.O. (2012). "The Effect of Using the Learning Cycle Method in Teaching Science on the Educational Achievement of the Sixth Graders". International journal of Educational Science, Vol. 4 No. 2, pp. 123-132.

Ratumanan, T. G., Laurens, T. (2011). Evaluasi Hasil Belajar yang Relevan dengan Kurikulum Barbasis Kompetensi. Surabaya: Unesa University Press.
Riduwan. (2010). Skala pengukuran variabel-variabel penelitian. Bandung: Alfabeta.

Risdiana, H., Suyatno, Sri, P. (2014). Implementasi Model 5e Learning Cycle untuk Meningkatkan Penguasaan Konsep dan Kemampuan Berpikir Kreatif Siswa SMA. Jurnal Penelitian Pendidikan Sains, Vol. 2, No. 3, pp. 174-183.

Sayuti, I., Rosmaini, S., Andayani. (2012). Penerapan Model Pembelajaran Learning Cycle 5e Untuk Meningkatkan Sikap Ilmiah dan Hasil Belajar Biologi Siswa Kelas Xi Ipa4 Sma Negeri 5 Pekanbaru. Jurnal Pendidikan Unri, Vol 3 No.1.

Slavin, R.E. (2011). Psikologi Pendidikan Teori dan Praktik. Edisi Kesembilan. Jakarta: PT. Indeks.

Susantini, R., Widha, S., Haryono. (2012). Pembelajaran Kimia Menggunakan Siklus Belajar 5E dan Inkuiri Bebas Dimodifikasi Ditinjau dari Kemampuan Berpikir Analisis dan Kreativitas Siswa. Jurnal Inkuiri, Vol 1 No. 1, pp. 60-68.

Thomson, S., Lisa, D.B., Sarah, B. (2014). PISA in Brief : Highlights from The Full Australian Report. ACER: Australian Council of Educational Research.

Tuckman, B. W. (1978). Conducting Educational Research Second Edition. USA: Harcourt Brace Jovanovich, Inc.

Tuna, A., Kacar, A. (2013). "The Effect of 5E Learning Cycle Model in Teaching Trigonometry on Students' Academic Achievement and The Permanence of Their Knowledge". International Journal on New Trends in Education and Their Implications, Vol. 4 Issue 1,Article 7, pp. 73-87.

Yalcin, F.A., Bayrakceke, S. (2010). The Effect of 5E Learning Model on Pre Service Science Teachers Achievement of Acids-Bases Subject. International Online Journal of Educational Sciences, Vol. 2 No. 2, pp. 508531.

Yamin, M. (2008). Paradigma Pendidikan Konstruktivistik. Jakarta: Gaung Persada Press Group. 